\title{
ANALISIS KEMAMPUAN KEUANGAN DAERAH KOTA MAKASSAR
}

\author{
Muh. Nur, R.
}

Fakultas Ekonomi Dan Bisnis, Universitas Muhammadiyah Makassar

\begin{abstract}
This study aims to answer a number of key issues, including: (1) What is the level of financial capacity in the city of Makassar, (2) What is the contribution of local revenue to the regional income and expenditure budget in the city of Makassar. Regional financial capacity in the era of regional autonomy is often measured using PAD performance. The method used in this study is descriptive quantitative and the types of relevant research such as triangles on regional financial data. The analysis technique used is the Routine Financial Ability Index (IKR) determined by BAPPENAS. While the data used is the APBD of the city of Makassar in 2011-2015. The results of the study show that regional financial independence ratios have an average yield of $50.60 \%$ or are in a pattern of participatory relationships. The ratio of the degree of fiscal decentralization and the ratio of routine ability index that shows the ability of regional finances is quite good, amounting to $30.92 \%$ and $37.42 \%$. In the harmony ratio, routine expenditure is greater than development spending. The contribution of PAD to the APBD was $31.03 \%$. By looking at the results of the analysis, the development of the financial capacity of Makassar City in 2011-2015 was considered quite good.
\end{abstract}

Keywords : Ratio, Finance, Performance, Independence

Correspondence to : muhnur@unismuh.ac.id

\begin{abstract}
ABSTRAK dianggap cukup baik.

\footnotetext{
Kata kunci : Rasio, Keuangan, Kinerja, Kemandirian

Korespondensi $\quad$ : muhnur@unismuh.ac.id
}

Penelitian ini bertujuan untuk menjawab beberapa permasalahan pokok, antara lain: (1) Bagaimana tingkat kemampuan keuangan daerah kota Makassar, (2) Bagaimana kontribusi pendapatan asli daerah terhadap anggaran pendapatan dan belanja daerah di kota Makassar. Kemampuan keuangan daerah dalam era otonomi daerah sering diukur dengan menggunakan kinerja PAD. Metode yang digunakan dalam penelitian ini adalah deskriptif kuantitatif dan jenis-jenis penelitian yang relevan seperti triangulasiterhadap data-data keuangan daerah. Teknik analisis yang digunakan adalah Indeks Kemampuan Keuangan Rutin (IKR) yang ditetapkan oleh BAPPENAS. Sedangkan data yang digunakan digunakan adalah APBD kota Makassar tahun 2011-2015. Hasil penelitian menunjukkan rasio kemandirian keuangan daerah yang memperoleh hasil rata-rata sebesar $50,60 \%$ atau berada pada pola hubungan partisipatif. Rasio derajat desentralisasi fiskal dan rasio indeks kemampuan rutin yang menunjukkan kemampuan keuangan daerah cukup baik, yaitu sebesar $30,92 \%$ dan 37,42\%. Pada rasio keserasian, pengeluaran belanja rutin lebih besar dibandingkan dengan belanja pembangunan. Konstribusi PAD terhadap APBD sebesar 31,03\%. Dengan melihat hasil analisis tersebut, perkembangan kemampuan keuangan Kota Makassar tahun 2011-2015

\section{PENDAHULUAN / INTRODUCTION}


Kemampuan keuangan daerah dalam era otonomi daerah sering diukur dengan menggunakan kinerja PAD. Besar-kecilnya penerimaan PAD seringkali dihubungkan dengan keberhasilan daerah dalam menjalani otonomi daerah. Pajak dan Retribusi daerah (yang merupakan komponen penyumbang PAD terbesar) seyogyanya mampu membiayai belanja pemerintah daerah (Kuncoro, 2007).

Pengukuran tingkat keuangan daerah yang banyak dilakukan saat ini antara lain dengan melihat rasio antara PAD dengan APBD. Prinsipnya, semakin besar sumbangan PAD terhadap APBD semakin kecil ketergantungan daerah dengan pemerintah pusat. satu hal yang perlu dicatat adalah peningkatan PAD bukan berarti daerah harus berlomba-lomba membuat pajak baru, tetapi diharapkan daerah memiliki tingkat kejelian yang tinggi dan kemampuan dalam melihat dan memanfaatkan sumber-sumber potensial yang dimiliki.

Berdasarkan latar belakang di atas, maka rumusan masalah yang akan dibahas adalah bagaimana tingkat kemampuan keuangan daerah tahun 2011-2015 di Kota Makassar dan bagaimana konstribusi Pendapatan Asli Daerah terhadap Anggaran Pendapatan dan Belanja daerah dalam menunjang pelaksanaan Otonomi Daerah di Kota Makassar?

\section{KAJIAN TEORI}

\section{Kebijakan Pengelolaan Keuangan Daerah}

Kebijakan pengelolaan keuangan daerah disesuaikan dengan situasi dan kondisi serta potensi daerah dengan berpedoman pada Undang-Undang Nomor 32 Tahun 2004 tentang Pemerintahan Daerah dan UndangUndang No. 33 Tahun 2004 tentang Perimbangan antara Pemerintah Pusat dan Daerah dan Peraturan Pemerintah Nomor 105 Tahun 2000 Tentang Pengelolaan dan Pertanggungjawaban Keuangan Daerah. Berdasarkan Peraturan Perundang-undangan tersebut, makadapat dikemukakan bahwa kebijakan umum pengelolaan keuangan daerah pada gambar berikut:

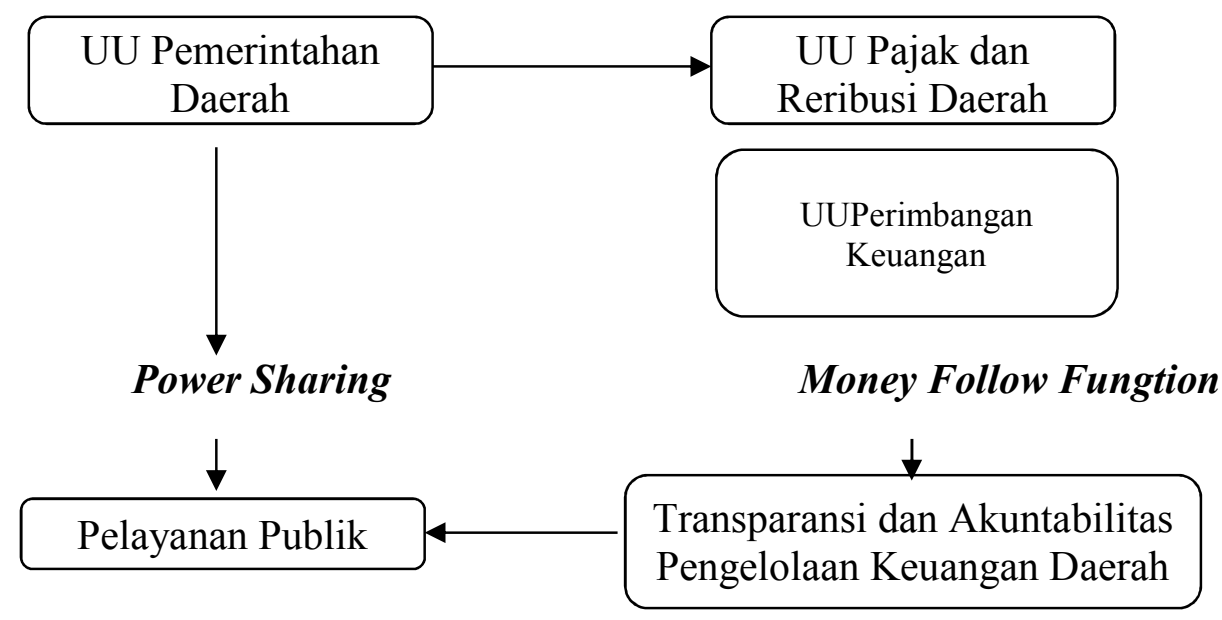

Gambar 1. Latar Belakang Pengaturan Keuangan Daerah

Disisi lain keuangan daerah adalah sebagai alat fiskal pemerintah daerah, merupakan bagian integral dari keuangan Negara dalam mengalokasikan sumbersumber ekonomi, memeratakan hasil pembangunan dan menciptakan stabilitas ekonomi selain stabiliats sosial politik. Peranan keuangan daerah semakin penting, selain karena keterbatasan dana yang dapat dialihkan ke daerah berupa Dana Alokasi 
Umum (DAU) dan dana Alokasi Khusus (DAK).

\section{Desentralisasi Fiskal}

Menurut Mahmudi (2010), desentralisasi fiskal adalah suatu proses distribusi anggaran dari tingkat pemerintahan yang lebih tinggi kepada pemerintahan yang lebih rendah untuk mendukung fungsi atrau tugas pemerintahan dan pelayanan publik sesuai dengan banyaknya kewenangan bidang pemeritahan yang dilimpahkan.

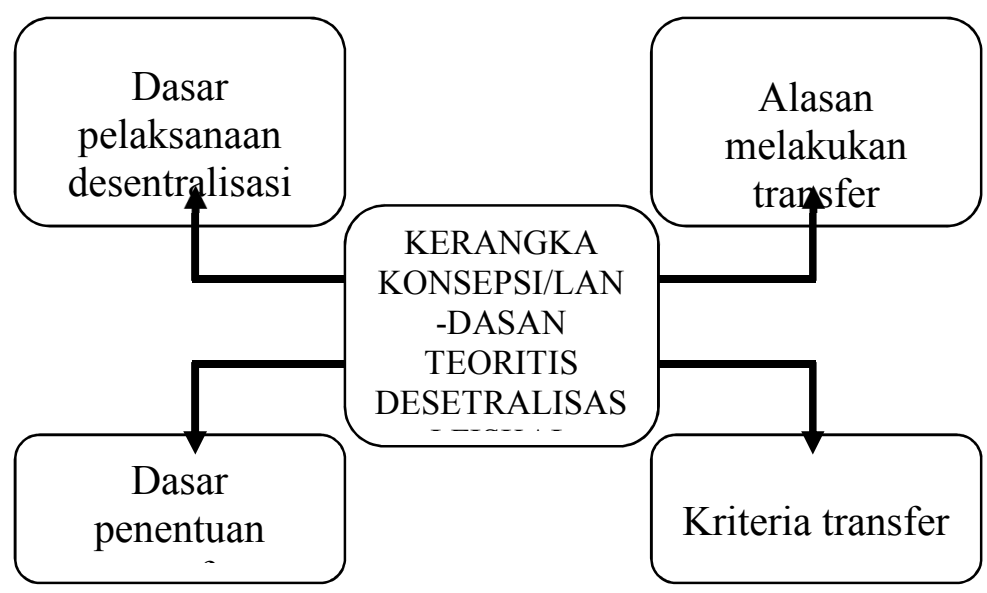

Gambar 2. Kerangka Teori Pelaksanaan Desentralisasi Fiskal

METODE PENELITIAN / METHODS Untuk melihat bagaimana alur penelitian, dapat lihat pada gambar berikut ini:

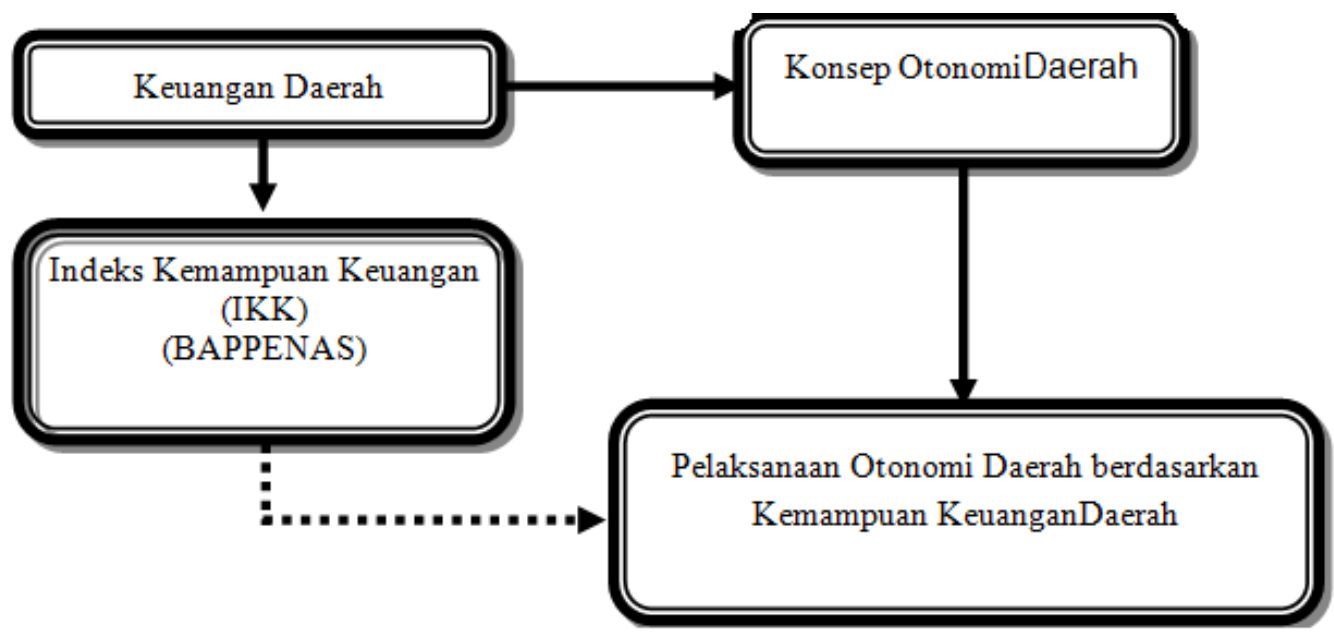

Gambar 3. Kerangka Konseptual

HASIL PENELITIAN DAN DISKUSI / RESULTS AND DISCUSSION

. Rasio Kemandirian Keuangan Daerah
Rincian tentang komponen sumbersumber pendapatan dari pihak ekstern berupa bantuan bantuan pemerintah pusat/provinsi, 
ditambah dengan jumlah pinjaman (jika ada) yang diperoleh oleh pemerintah Kota Makassar pada Tabel 5.1.
Hasil perhitungan Rasio Kemandirian Keuangan Daerah dapat dilihat dalam tabel 5 dan gambar.1.

Tabel 1. Perhitungan Rasio Kemandirian APBD Kota Makassar

\begin{tabular}{|c|c|c|c|c|}
\hline TA & PAD & TRANSFER & $\begin{array}{c}\text { RASIO } \\
\text { KEMANDIRIAN }\end{array}$ & $\begin{array}{c}\text { POLA } \\
\text { HUBUNGAN }\end{array}$ \\
\hline 2011 & 345.350 .562 .825 & 905.316 .278 .541 & $38,14 \%$ & Konsultatif \\
\hline 2012 & 484.972 .799 .508 & 1.105 .463 .603 .654 & $43,87 \%$ & Konsultatif \\
\hline 2013 & 621.247 .679 .844 & 1.161 .279 .547 .759 & $53,5 \%$ & Partisipatif \\
\hline 2014 & 730.988 .641 .340 & 1.251 .876 .573 .939 & $58,4 \%$ & Partisipatif \\
\hline 2015 & 828.871 .892 .852 & 1.402 .767 .592 .484 & $59,08 \%$ & Partisipatif \\
\hline \multicolumn{5}{|c|}{ RATA-RATA } \\
\hline
\end{tabular}

Sumber : Data diolah 2017

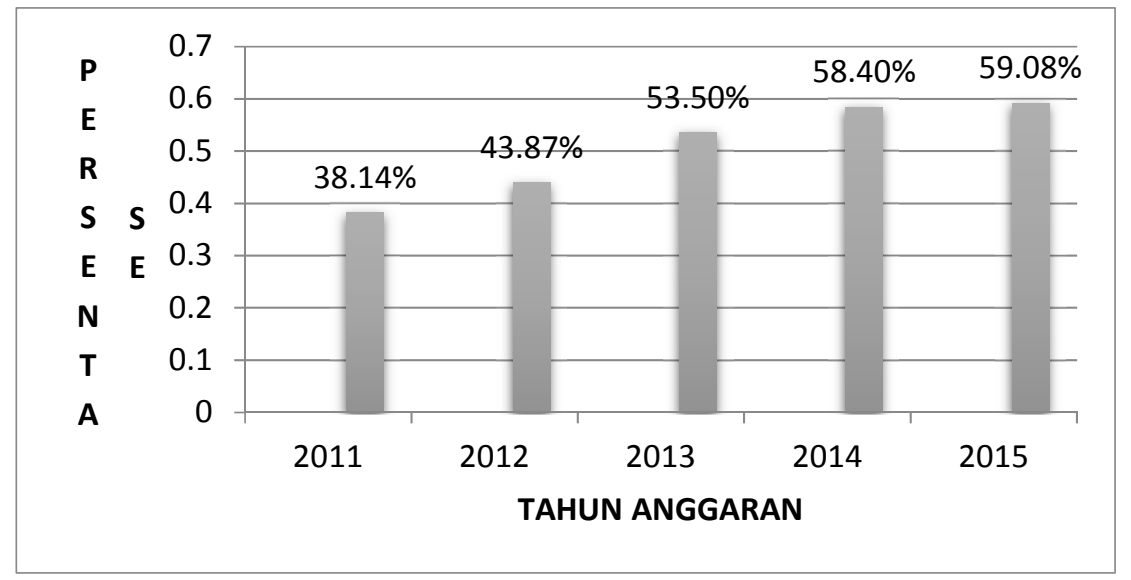

Gambar 4. Hasil Perhitungan Rasio Kemandirian Keuangan Kota Makassar Tahun Anggaran 2011-2015

Menurut hasil perhitungan dan Gambar 1, selama lima tahun terakhir rasio kemandirian keuangan daerah Kota Makassar memperlihatkan trend kenaikan ke pola hubungan partisipatif. .

\section{Rasio Derajat Desentralisasi Fiskal}

Tabel 2. Perhitungan Rasio Derajat Desentralisasi Fiskal Kota Makassar Tahun Anggaran 2011-2015

\begin{tabular}{|l|c|c|c|l|}
\hline \multicolumn{1}{|c|}{$\begin{array}{c}\text { Tahun } \\
\text { Anggaran }\end{array}$} & $\begin{array}{c}\text { PAD } \\
(\text { Rp) }\end{array}$ & $\begin{array}{c}\text { TPD } \\
(\mathbf{R p})\end{array}$ & \multicolumn{1}{c|}{$\begin{array}{c}\text { Kemampuan } \\
\text { Keuangan }\end{array}$} \\
\hline 2011 & $345.350 .562 .825,00$ & $1.883 .077 .957 .274,75$ & $18,33 \%$ & Kurang \\
\hline 2012 & $484.972 .799 .508,00$ & $2.046 .125 .413 .850,00$ & $23,70 \%$ & Cukup \\
\hline 2013 & $621.247 .679 .844,00$ & $1.085 .366 .097 .556,00$ & $57,23 \%$ & Sangat Baik \\
\hline 2014 & $730.988 .641 .340,00$ & $2.629 .817 .615 .252,00$ & $27,29 \%$ & Cukup \\
\hline 2015 & $828.871 .892 .852,66$ & $2.952 .609 .910 .737,09$ & $28,07 \%$ & Cukup
\end{tabular}
2.6 berikut ini:

Hasil perhitungan Rasio Derajat Desentralisasi Fiskal dapat dilihat dalam tabel 
Balance Vol. XVII No. 2 | Juli 2019

\begin{tabular}{|l|l|l|}
\hline Rata-rata & $30,92 \%$ & Sedang \\
\hline
\end{tabular}

Sumber: Data diolah, 2017

Berdasarkan jumlah rata-rata rasio keuangan Kota Makassar masih berada pada derajat desentralisasi fiskal, kemampuan tingkat kemampuan yang sedang.

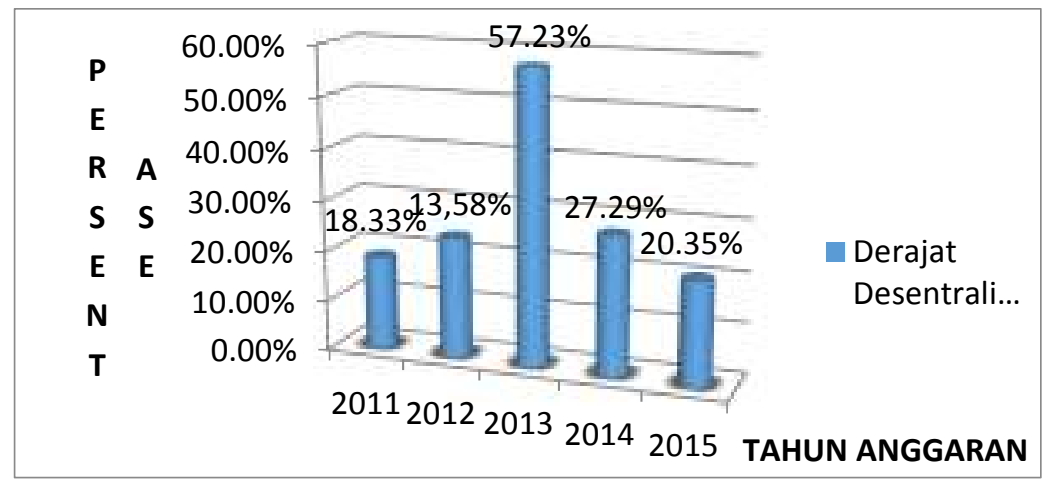

Gambar 5.Hasil Perhitungan Rasio Derajat Desentralisasi Fiskal Kota Makassar Tahun 2011-2015

Sedangnya perolehan persentase yang dimiliki oleh Kota Makassar menunjukkan bahwa pemerintah kota belum cukup mampu membiayai pengeluarannya sendiri.

Rasio Indeks Kemampuan Rutin
Dalam penelitian ini, pengeluaran rutin atau belanja rutin diperoleh dari bagian belanja operasi. Berikut adalah rincian komponen pengeluaran/belanja rutin Kota Makassar yang disajikan pada tabel 3.:

Tabel 3. Pengeluaran Rutin Kota Makassar Tahun Anggaran 2011-2015

\begin{tabular}{|c|c|c|c|c|c|}
\hline \multirow{2}{*}{ URAIAN } & 2011 & 2012 & 2013 & 2014 & 2015 \\
\cline { 2 - 6 } & & $1.643 .812 .879 .750,77$ & $937.797 .498 .000,00$ & $2.142 .009 .298 .567,13$ & $2.378 .540 .551 .393,25$ \\
\hline $\begin{array}{c}\text { Total } \\
\text { Pengeluaran } \\
\text { Rutin }\end{array}$ & $\mathbf{1 . 5 3 8 . 4 6 7 . 4 1 5 . 3 4 8 , 2 3}$ & $\mathbf{5}$ & \multicolumn{5}{|c|}{ TAHUN ANGGARAN } \\
\hline
\end{tabular}

Sumber: Data diolah, 2017

Berikut adalah hasil perhitungan rasio

Indeks Kemampuan Rutin (IKR) Kota

Makassar tahun anggaran 2011-2015:

Tabel 4. Perhitungan Rasio Indeks Kemampuan Rutin Kota Makassar

Tahun Anggaran 2011-2015

\begin{tabular}{|c|c|c|c|c|}
\hline $\begin{array}{c}\text { Tahun } \\
\text { Anggaran }\end{array}$ & PAD & Pengeluaran Rutin & Kemampuan \\
$(\mathbf{R p})$ & $(\mathbf{R p )}$ & Keuangan \\
\hline 2011 & $345.350 .562 .825,00$ & $1.538 .467 .415 .348,23$ & $22,44 \%$ & Kurang \\
\hline 2012 & $484.972 .799 .508,00$ & $1.643 .812 .879 .750,77$ & $29,50 \%$ & Kurang \\
\hline
\end{tabular}


Balance Vol. XVII No. 2 | Juli 2019

\begin{tabular}{|l|l|r|r|c|}
\hline 2013 & $621.247 .679 .844,00$ & $937.797 .498 .000,00$ & $66,24 \%$ & Baik \\
\hline 2014 & $730.988 .641 .340,00$ & $2.142 .009 .298 .567,13$ & $34,12 \%$ & Kurang \\
\hline 2015 & $828.871 .892 .852,66$ & $2.378 .540 .551 .393,25$ & $34,84 \%$ & Kurang \\
\hline \multicolumn{5}{|c|}{ Rata-Rata } \\
\hline
\end{tabular}

Sumber: Data diolah, 2017

Dari tabel 2.8, dapat disimpulkan bahwa Indeks Kemampuan Rutin selama lima tahun (2011-2015) pada pemerintahan Kota Makassar masih dalam skala yang kurang, karena masih berada dalam skala rata rata $37,42 \%$ (rata-rata IKR) dan ini berarti bahwa
Pendapatan Asli Daerah (PAD) mempunyai kemampuan yang kurang untuk membiayai pengeluaran rutin, hal ini terjadi karena PAD Kota Makassar sangat kecil jika dibandingkan dengan nilai belanja rutin.

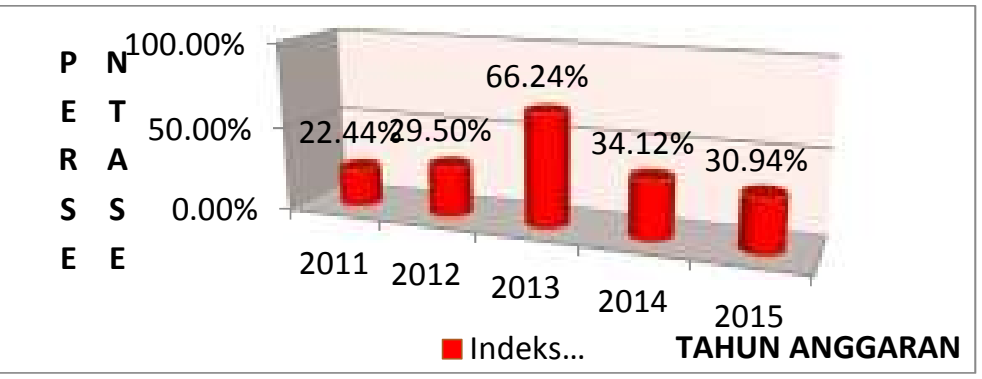

Gambar 6. Hasil Perhitungan Indeks Kemampuan Rutin Kota Makassar Tahun Anggaran 2011-2015

Berdasarkan gambar.3, maka terlihat bahwa terjadi kenaikan indeks kemampuan rutin pada tahun 2013 yang kemudian menurun lagi hingg tahun 2015.

\section{Rasio Keserasian}

Dibawah ini, akan dipaparkan belanja pembangunan yang tertera pada Tabel 2.5.

Tabel 5. Belanja Pembangunan Kota Makassar Tahun Anggaran 2011-2015

\begin{tabular}{|c|c|c|c|c|c|}
\hline Uraian & $\mathbf{2 0 1 1}$ & $\mathbf{2 0 1 2}$ & $\mathbf{2 0 1 3}$ & $\mathbf{2 0 1 4}$ & $\mathbf{2 0 1 5}$ \\
\hline $\begin{array}{c}\text { Belanja } \\
\text { Pembangunan }\end{array}$ & $168.460 .026 .058,00$ & $318.062 .312 .409,00$ & $418.662 .712 .239,00$ & $463.260 .544 .761,22$ & $673.026 .825 .829,00$ \\
\hline
\end{tabular}

Sumber: Data diolah, 2017

Tabel 6. Perhitungan Rasio Keserasian Kota Makassar Tahun Anggaran 2011-2015

\begin{tabular}{|c|c|c|c|c|c|c|c|c|}
\hline \multirow{2}{*}{ No } & \multirow{2}{*}{$\begin{array}{c}\text { Tah } \\
\text { un } \\
\text { Ang } \\
\text { gara } \\
\text { n }\end{array}$} & \multirow{2}{*}{$\begin{array}{c}\text { Total Belanja } \\
\text { (Rp) }\end{array}$} & \multicolumn{2}{|c|}{ Realisasi Belanja Rutin } & \multicolumn{2}{|c|}{$\begin{array}{l}\text { Realisasi Belanja } \\
\text { Pembangunan }\end{array}$} & \multirow{2}{*}{$\begin{array}{c}\text { Rasio } \\
\text { Belanja } \\
\text { Rutin }\end{array}$} & \multirow{2}{*}{$\begin{array}{c}\text { Rasio } \\
\text { Belanja } \\
\text { Pemban } \\
\text { gunan }\end{array}$} \\
\hline & & & $\mathbf{R p}$ & $\begin{array}{c}\text { Perke } \\
\text { mbang } \\
\text { an }\end{array}$ & $\mathbf{R p}$ & $\begin{array}{c}\text { Perkemb } \\
\text { angan }\end{array}$ & & \\
\hline 1 & 2011 & $1.708 .953 .042 .766,23$ & $1.538 .467 .415 .348,23$ & - & $168.460 .026 .058,00$ & - & $90,02 \%$ & $9,85 \%$ \\
\hline 2 & 2012 & $1.960 .970 .441 .159,77$ & $1.643 .812 .879 .750,77$ & $6,84 \%$ & $318.062 .312 .409,00$ & $88,80 \%$ & $83,82 \%$ & $16,21 \%$ \\
\hline 3 & 2013 & $2.226 .657 .246 .457,58$ & $1.807 .799 .453 .400,00$ & $9,97 \%$ & $418.662 .712 .239,00$ & $31,62 \%$ & $81,16 \%$ & $18,80 \%$ \\
\hline 4 & 2014 & $2.605 .269 .843 .328,35$ & $2.142 .009 .298 .567,13$ & $18,5 \%$ & $463.260 .544 .761,22$ & $10,65 \%$ & $82,22 \%$ & $17,78 \%$ \\
\hline 5 & 2015 & $3.061 .176 .650 .637,25$ & $2.378 .540 .551 .393,25$ & $1,10 \%$ & $673.026 .825 .829,00$ & $45,28 \%$ & $77,70 \%$ & $21,98 \%$ \\
\hline \multicolumn{7}{|c|}{ Rata-Rata } & $82,98 \%$ & $16,92 \%$ \\
\hline
\end{tabular}

Sumber: Data diolah, 2017 
Berdasarkan Undang-undang Nomor 32 dan 33 Tahun 2004, implikasi dari pemberian kewenangan otonomi ini menuntut daerah untuk melaksanakan pembangunan di segala bidang, Pembangunan yang dilaksanakan akan banyak memberikan manfaat bagi daerah, diantaranya:

1. Meningkatkan kualitas dan kuantitas pelayanan masyarakat.

2. Mendorong perkembangan perekonomian daerah.

3. Mendorong peningkatan pembangunan daerah di segala bidang.
4. Meningkatkan taraf hidup dan kesejahteraan masyarakat.

5. Meningkatkan pendapatan asli daerah.

6. Mendorong kegiatan investasi

Hasil perhitungan rasio keserasian Kota Makassar tahun anggaran 2007-2011 yang menunjukkan masih rendahnya rasio belanja pembangunan apabila dibandingkan dengan rasio belanja rutin. Dimana, hasil rata-rata dari rasio belanja pembangunan sebesar $37,20 \%$ dan rata-rata rasio belanja rutin sebesar $62,80 \%$, terdapat gap sebesar $25,60 \%$. Berikut adalah gambar yang menunjukkan perbedaan jumlah tersebut

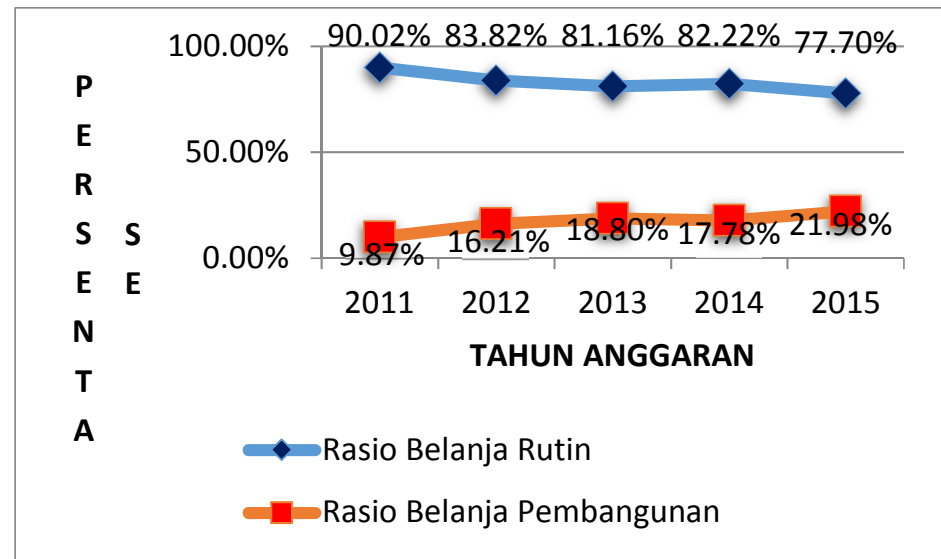

\section{Gambar 7. Hasil Perhitungan Rasio Keserasian Kota Makassar Tahun Anggaran 2011-2015}

Meskipun terdapat banyak sumbersumber pembiayaan untuk pembangunan daerah berdasarkan UU No 33 Tahun 2004 pasal 10, namun faktanya pemerintah Kota Makassar yang lebih condong pada ekonomi kerakyatan belum memperhatikan pembangunan daerah, walaupun belanja pembangunan naik tetapi relatif kecil.

\section{Rasio Pertumbuhan}

Rasio pertumbuhan (growth ratio) mengukur seberapa besar kemampuan
Pemerintah daerah dalam mempertahankan dan meningkatkan keberhasilan yang telah dicapai dari periode ke periode berikutnya. Rumus yang digunakan untuk menghitung Rasio pertumbuhan adalah sebagai berikut :

Dimana:

$$
r=\frac{P n-P o}{P o} \times 100 \%
$$

Pn = Data yang dihutung pada tahun ke-n

Po = Data yang dihitung pada tahun ke-0

$\mathrm{R} \quad=$ Pertumbuhan

Tabel 7. Perhitungan Rasio Pertumbuhan Kota Makassar

Tahun Anggaran 2011-2015 
Balance Vol. XVII No. 2 | Juli 2019

\begin{tabular}{|c|c|c|c|c|c|c|}
\hline \multirow{2}{*}{ No } & \multirow{2}{*}{ Keterangan } & \multicolumn{5}{|c|}{ Tahun Anggaran } \\
\hline & & 2011 & 2012 & 2013 & 2014 & 2015 \\
\hline \multirow[t]{2}{*}{1} & PAD & $345.350 .562 .825,00$ & $484.972 .799 .508,00$ & $621.247 .679 .844,00$ & $730.988 .641 .340,67$ & $828.871 .892 .852,66$ \\
\hline & Pertumbuhan & - & $40,42 \%$ & $28,09 \%$ & $17,66 \%$ & $13,40 \%$ \\
\hline \multirow[t]{2}{*}{2} & $\begin{array}{l}\text { Total } \\
\text { Pendapatan }\end{array}$ & $1.883 .077 .957 .274,75$ & $2.046 .125 .413 .850,00$ & $2.601 .356 .102 .560,00$ & $2.629 .817 .615 .252,03$ & $2.952 .609 .910 .737,09$ \\
\hline & Pertumbuhan & - & $8,65 \%$ & $27,13 \%$ & $1,09 \%$ & $12,27 \%$ \\
\hline \multirow[t]{2}{*}{3} & Belanja Rutin & $1.538 .467 .415 .348,23$ & $1.643 .812 .879 .750,77$ & $1.807 .799 .453 .400,00$ & $2.142 .009 .298 .567,13$ & $2.378 .540 .551 .393,25$ \\
\hline & Pertumbuhan & - & $6,84 \%$ & $9,97 \%$ & $18,48 \%$ & $11,04 \%$ \\
\hline \multirow[t]{2}{*}{4} & $\begin{array}{l}\text { Belanja } \\
\text { Pembangunan }\end{array}$ & $168.460 .026 .058,00$ & $318.062 .312 .409,00$ & $418.662 .712 .239,00$ & $463.260 .544 .761,22$ & $673.026 .825 .829,00$ \\
\hline & Pertumbuhan & - & $88,8 \%$ & $31,63 \%$ & $10,65 \%$ & $45,28 \%$ \\
\hline
\end{tabular}

Sumber: Data diolah, 2017

Berdasarkan hasil perhitungan pada tabel 2.11 kondisi pertumbuhan APBD Kota Makassar dapat disimpulkan bahwa APBD pada tahun anggaran 2011-2015 menunjukkan pertumbuhan rata-rata yang negatif. Hal ini diakibatkan pertumbuhan nilai PAD dan total pendapatan daerah kurang diikuti oleh pertumbuhan belanja pembangunan. Artinya, pemerintah Kota Makassar belum mampu mempertahankan dan meningkatkan pertumbuhannya dari periode yang satu ke periode berikutnya yang disebabkan masih fluktuatifnya pertumbuhan belanja pembangunan, dan belanja rutin yang terus bertambah sejak lima tahun belakangan..

Untuk lebih jelasnya, dibawah ini disajikan gambar yang menunjukkan pertumbuhan APBD yang dilihat dari berbagai komponen penyusunan APBD yang terdiri dari PAD, total pendapatan daerah, belanja rutin, dan belanja pembangunan.

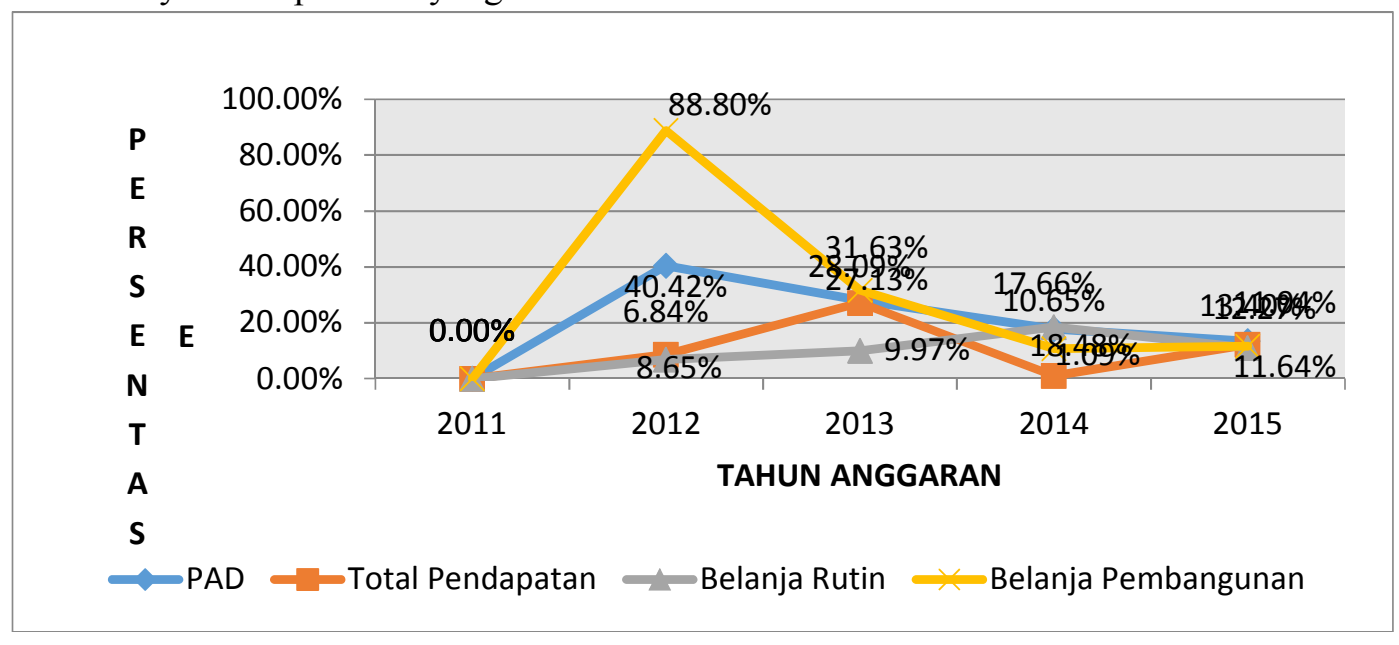

Gambar 8. Hasil Perhitungan Rasio Pertumbuhan Kota Makassar Tahun Anggaran 2011-2015

\section{Kontribusi Pendapatan Asli Daerah} Terhadap APBD

Meskipun terdiri dari empat sumber, hingga saat ini hanya Pajak Daerah dan Retribusi Daerah yang menyumbang secara siginifkan terhadap total penerimaan PAD suatu Daerah. Sementara sumber yang berasal dari BUMD dan Lain PAD yang sah masih belum berperan, dimana hal tersebut dapat dicermati pada tabel berikut:

Adapun rekapitulasi mengenai target dan realisasi penerimaan Pendapatan Asli 
Daerah Kota Makassar tahun anggaran 2011-

2015 sebagai berikut:

Tabel 8. Rekapitulasi Target dan Realisasi Pendapatan Asli Daerah Kota Makassar Tahun Anggaran 2011-2015

\begin{tabular}{|c|c|c|c|}
\hline Tahun & Target & Realisasi & \% \\
\hline 2011 & 345.335 .311 .000 & 345.350 .562 .825 & $100 \%$ \\
\hline 2012 & 441.234 .952 .000 & 487.390 .342 .729 & $110,4 \%$ \\
\hline 2013 & 563.891 .202 .000 & 621.247 .679 .844 & $110,2 \%$ \\
\hline 2014 & 831.661 .964 .000 & 730.988 .641 .340 & 87,90 \\
\hline 2015 & 992.147 .612 .000 & 828.871 .892 .852 & $83,54 \%$ \\
\hline
\end{tabular}

Sumber: Dispenda Kota Makassar, Data diolah, 2017

Tabel 9. Konstribusi Pendapatan Asli Daerah terhadap Total Pendapatan APBD Kota Makassar Tahun Anggaran 2011-2015

\begin{tabular}{|c|c|c|c|c|c|}
\hline \multirow{2}{*}{ No } & \multirow{2}{*}{ TA } & \multirow{2}{*}{$\begin{array}{c}\text { Total Pendapatan } \\
\text { APBD (Rp) }\end{array}$} & \multicolumn{2}{|c|}{ Pendapatan Asli Daerah } & \multirow{2}{*}{$\%$} \\
\cline { 4 - 5 } & & & Rp & Perkembangan & \\
\hline 1 & 2011 & $1.883 .077 .957 .274,75$ & $345.350 .562 .825,00$ & - & $18,33 \%$ \\
\hline 2 & 2012 & $2.046 .125 .413 .850,00$ & $484.972 .799 .508,00$ & $40,43 \%$ & $23,70 \%$ \\
\hline 3 & 2013 & $1.085 .366 .097 .556,00$ & $621.247 .679 .844,00$ & $28,09 \%$ & $57,23 \%$ \\
\hline 4 & 2014 & $2.629 .817 .615 .252,03$ & $730.988 .641 .340,67$ & $17,66 \%$ & $27,80 \%$ \\
\hline 5 & 2015 & $2.952 .609 .910 .737,09$ & $828.871 .892 .852,66$ & $13,40 \%$ & $28,07 \%$ \\
\hline \multicolumn{7}{r}{} & Rata-Rata & & $23,14 \%$ & $31,03 \%$ \\
\hline
\end{tabular}

Sumber: APBD Kota Makassar TA 2011-2015, Data Diolah, 2017.

Dari tabel, dapat diliat PAD mengalami peningkatan secara signifikan dalam lima tahun terakhir. Meskipun trend PAD meningkat seiring dengan adanya diskresi dari pemerintah pusat untuk menyerahkan beberapa sumber-sumber pendapatan yang tadinya dikuasai oleh pemerintah pusat yang kemudian diserahkan kepada pemerintah daerah untuk menagih, menarik beberapa jenis pajak sudah diserahkan kepada daerah, sehingga trend PAD meningkat, meskipun

\section{KESIMPULAN / CONCLUSSION}

\section{Kesimpulan}

Dari hasil penelitian dan hasil analisis data dapat diambil kesimpulan

sebagai berikut :

1. Tingkat kemampuan keuangan daerah Kota Makassar tahun anggaran 20112015 dianggap masih kurang. Hal ini demikian tetap saja PAD Kota Makassar belum mampu menutup seluruh belanja daerah.

Rendahnya rata rata konstribusi PAD terhadap Total Pendapatan APBD, mengharuskan pemerintah kota lebih memperketat aturan yang ada, serta lebih lihai mencari sumber-sumber pendanaan alternatif. Salah satunya adalah pendirian Badan Usaha Milik Daerah (BUMD) yang berbentuk Perusahaan Daerah.

dapat dilihat berdasarkan hasil perhitungan rasio:

a. Rasio kemandirian keuangan daerah selama lima tahun terakhir yang menghasilkan jumlah rata-ratanya sebesar 50,60\% dengan pola hubungan yang partisipatif. Dari hasil tersebut, tergambar dengan jelas bahwa pemerintah Kota Makassar 
ketergantungannya mulai berkurang terhadap sumber-sumber dana bantuan dari pihak ekstern, baik dari pemerintah pusat maupun dari pemerintah provinsi, dengan komponen bantuan terbesar adalah Dana Alokasi Umum (DAU) dan Dana Penyesuaian.

b. Rasio Derajat Desentralisasi Fiskal, selama 5 (lima) tahun menunujukkan angka rata-rata sebesar $30,92 \%$ dengan kemampuan keuangan yang tergolong sedang. Hasil ini menunjukkan bahwa pemerintah Kota Makassar cukup mampu membiayai pengeluarannya sendiri. Pemerintah Kota Makassar masih cukup bergantung kepada pemerintah pusat dalam hal pembiayaan pengeluaran.

c. Berdasarkan kemampuan PAD untuk membiayai pengeluaran rutin daerah, yang sering disebut juga dengan Rasio IKR (Indeks Kemampuan Rutin) rata-rata hanya sebesar $37,42 \% \%$ dengan pola kemampuan keuangan yang masih berada dalam interval $20,01 \%$ - 40,00\% yang dinilai kurang. Artinya, PAD Kota Makassar belum mampu membiayai belanja rutin yang dilakukan oleh pemerintah kota.

d. Berdasarkan hasil perhitungan rasio keserasian, pemerintah Kota Makassar masih lebih memprioritaskan belanja rutin daripada belanja pembangunan. Hasil rata-rata dari rasio pembangunan sebesar 16,92\% dan rasio belanja rutin sebesar 82,98\%. Terdapat kesenjangan yang besar antara belanja pembangunan dan belanja rutin. Angka-angka ini menunjukkan bahwa pemerintah kota belum memperhatikan pembangunan daerah. Hal ini disebabkan keterbatasan dana yang dimiliki oleh pemerintah kota sehingga pemerintah kota lebih berkonsentrasi pada pemenuhan belanja rutin dan penghematan pada belanja lainnya.

e. Berdasarkan rasio pertumbuhan (growth ratio), PAD Kota Makassar mengalami pertumbuhan ditiap periode tahun anggaran (2011-2015), Total Pendapatan Daerah jugamengalami pertumbuhan pada lima tahun terakhir, sama halnya dengan belanja rutin yang juga mengalami pertumbuhan, dan belanja pembangunan mengalami kenaikan yang tidak signifikan dari tahun 20112015. Dari hasil perhitungan tersebut, dapat disimpulkan bahwa kondisi pertumbuhan APBD Kota Makassar menunjukkan rata-rata yang negatif, karena pertumbuhan PAD dan TDP tidak diikuti oleh pertumbuhan belanja pembangunan yang signifikan, melainkan diikuti oleh kenaikan belanja rutin yang besar. Berdasarkan Rasio Pertumbuhan, konstribusi Pendapatan Asli Daerah Kota Makassar terhadap Anggaran Pendapatan dan Belanja Daerah tahun anggaran 2011-2015 dinilai masih rendah, yaitu $31,03 \%$

2. Konstribusi Pendapatan Asli Daerah terhadap Anggaran Pendapatan dan Belanja Daerah Kota Makassa tahun anggaran 2011-2015 masih relatif kecil. Berdasarkan hasil perhitungan konstribusi $\mathrm{PAD}$, hasil rata-rata yang diperoleh adalah sebesar 31,03\%. Artinya, rata konstribusi PAD terhadap APBD selama lima tahun hanya sebesar $31,03 \%$. Merupakan angka yang rendah.. Rendahnya konstribusi PAD terhadap Total Pendapatan APBD, mengharuskan pemerintah kota lebih memperketat aturan yang ada, serta lebih lihai mencari 
sumber-sumber pendanaan alternatif. Salah satunya adalah mengeksplorasi potensi pajak yang ada di kota Makassar.

\section{Saran}

Berdasarkan hasil analisis data dan kesimpulan tentang kinerja keuangan Pemerintah kota Makassar, penulis mencoba mengajukan beberapa saran. Saran-saran tersebut adalah sebagai berikut:

1. Mengingat terbatasnya jumlah dan jenis sumber-sumber Pendapatan Asli Daerah, maka diperlukan penyerahan beberapa sumber keuangan nasional yang potensial untuk dikelola dan dipungut sendiri oleh daerah dan menjadi penerimaan PAD.

2. Penelitian ini hanya menganalisis beberapa komponen dalam perkembangan APBD, diharapkan untuk penelitian selanjutnya dapat menganalisis seluruh komponen yang terdapat dalam APBD sehingga akan lebih lengkap.

3. Penelitian ini hanya menggunakan beberapa model analisis rasio keuangan, untuk penelitian selanjutnya diharapkan dapat menggunakan seluruh model analisis rasio keuangan sehingga hasil analisisnya lebih lengkap dan menyeluruh.

4. Penelitian ini hanya dilakukan pada tahun anggaran 2011-2015 di Kota Makassar saja, diharapkan untuk penelitian selanjutnya tahun anggaran lebih up to date dan obyek penelitiannya dilakukan dibeberapa kota sehingga ada perbandingan antara kota yang satu dengan kota yang lain.

\section{DAFTAR PUSTAKA / BIBLIOGRAPHY}

Adi, Priyo Hari. 2012. Kemampuan Keuangan Daerah Dalam Era Otonomi dan Relevansinya Dengan Pertumbuhan Ekonomi (Studi Pada Kabupaten dan Kota Se Jawa-Bali. Kritis Vol XXI. No.1 Januari-April 2012.
Badan Perencanaan dan Pembangunan Nasional, Direktorat Pengembangan Otonomi Daerah. 2003. Peta Kemampuan Keuangan Provinsi dalam Era Otonomi Daerah: Tinjauan atas Kinerja PAD, dan Upaya Yang Dilakukan Daerah. (Online) (www.bappenas.go.id. 2015)..

Erlina, H., Maro'ah, S., \& Mochklas, M. 2017. Efektifitas Penerapan Metode Feedback Tool For Operations (Fto) Dalam Penilaian Kinerja Untuk Peningkatan Karir Karyawan Di Pt Hm Sampoerna Pasuruan, Jawa Timur. Jurnal EKSEKUTIF, 14(2): 262-276

Fatihudin, D., and Mochklas, M. (2018). How Measuring Financial Performance. International Journal of Civil Engineering and Technology, 9(6), 553-557

Mahmudi. 2010. Buku Seri Membudayakan Akuntabilitas Publik: Analisis Laporan Keuangan Pemerintah Daerah Panduan bagi Eksekutif, DPRD, dan Masyarakat dalam Pengambilan Keputusan Ekonomi, Sosial, dan Politik. Yogyakarta: Unit Penerbit dan Percetakan Sekolah Tinggi Ilmu Manajemen YKPN.

Mochklas, M., \& Setiawan, T. 2018. Sistem Informasi Manajemen. Surabaya: TS Publisher.

Muluk, Khairul. 2009. Peta Konsep Desentralisasi dan Pemerintahan Daerah. Malang: ITS Press.

Peraturan Pemerintah RI. 2005. Peraturan Pemerintah Nomor 58 Tahun 2005 Tentang Pengelolaan Keuangan Daerah.

Peraturan Pemerintah RI. 2000. Peraturan Pemerintah Nomor 105 Tahun 2000 Tentang Pengelolaan dan Pertanggungjawaban Keuangan Daerah.

Rinaldi, Udin. 2012. Kemandirian Keuangan Dalam Pelaksanan Otonomi Daerah. Eksos. Vol 8. No. 2 Juni 2012.

Undang-Undang RI. 2009. Undang-Undang Republik IndonesiaNomor 28 Tahun 2009 tentang Pajak Daerah dan Retribusi Daerah.

Undang-Undang RI. 2004. Undang-Undang Republik Indonesia Nomor 32 
Balance Vol. XVII No. 2 | Juli 2019

Tahun 2004 tentang Pemerintah Daerah.

Wahyuni, 2010. Analisis Rasio Untuk Mengukur Kinerja Keuangan Daerah Pemerintah Kota Malang. El Muhasaba, Vol 1, No. 1 AgustusNovember 2010.
Wulandari, Anita. 2001. Kemampuan Keuangan DaerahKabupaten Banyuwangi. Jurnal Kebijakan dan Adminislrasi Publik Vol 5 No 2 November AprilJuli 2001. 